\title{
Sympodiomyces attinorum sp. nov., a yeast species associated with nests of the leaf-cutting ant Atta sexdens
}

\author{
Solange C. Carreiro, ${ }^{1}$ Fernando C. Pagnocca, ${ }^{2}$ Maurício Bacci Jr, ${ }^{2}$ \\ Marc-André Lachance, ${ }^{3}$ Odair C. Bueno, ${ }^{2}$ Maria José A. Hebling, ${ }^{2}$ \\ Carla C. C. Ruivo ${ }^{2}$ and Carlos A. Rosa ${ }^{4}$ \\ ${ }^{1}$ Laboratório de Microbiologia de Alimentos, Campus Universitário de Palmas, Fundação \\ Universidade Federal do Tocantins, Palmas, Tocantins, 77020-210, Brazil \\ ${ }^{2}$ Centro de Estudos de Insetos Sociais, CEIS, CP 199, Universidade Estadual Paulista, \\ Rio Claro, São Paulo, 13506-900, Brazil \\ ${ }^{3}$ Department of Biology, University of Western Ontario, London, Ontario, Canada N6A 5 B7 \\ ${ }^{4}$ Departamento de Microbiologia, ICB, CP 486, Universidade Federal de Minas Gerais, \\ Belo Horizonte, MG, 31270-901, Brazil
}

Correspondence Solange C. Carreiro solange@uft.edu.br

\begin{abstract}
Four strains of a novel yeast species were isolated from laboratory nests of the leaf-cutting ant Atta sexdens in Brazil. Three strains were found in older sponges and one was in a waste deposit in the ant nests. Sequencing of the D1/D2 region of the large-subunit rRNA gene showed that the novel species, named Sympodiomyces attinorum sp. nov., is phylogenetically related to Sympodiomyces parvus. Unlike Sympodiomyces parvus, Sympodiomyces attinorum can ferment glucose, assimilate methyl $\alpha$-D-glucoside, salicin and citrate, and grow at $37^{\circ} \mathrm{C}$, thus enabling these two species to be distinguished. Differentiation from other related species is possible on the basis of other growth characteristics. The type strain of Sympodiomyces attinorum is UNESP-S156 ${ }^{\top}\left(=\right.$ CBS $9734^{\top}=$ NRRL Y $\left.-27639^{\top}\right)$.
\end{abstract}

Yeasts are frequently isolated from nests of the leaf-cutting ant Atta sexdens. This ant uses plant materials to cultivate a symbiotic filamentous fungus, which is the main food for the broods. The yeasts grow in association with the fungus garden, which consists of mycelium growing on the plant material carried to the nests by the ants. Yeasts are also found in waste deposits, the material discharged by the ants (Carreiro et al., 1997). The role of the yeasts in the symbiosis is not clear, but the ability of many yeast strains to degrade some plant polysaccharides may contribute to the availability of carbon sources for the symbiotic filamentous fungus (Carreiro, 2000).

During a survey of yeasts associated with laboratory nests of A. sexdens, Carreiro et al. (1997) found several yeasts, among which the dominant species were identified physiologically as Candida homilentoma, Debaryomyces hansenii and Torulaspora delbrueckii. However, sequence analysis of the D1/D2 domain of the large-subunit rRNA gene showed that most of the isolates identified as Debaryomyces hansenii and Torulaspora delbrueckii were, in fact, representatives of Pichia guilliermondii. Three strains previously

The GenBank/EMBL/DDBJ accession number for the large-subunit rRNA gene sequence of strain UNESP-S156 ${ }^{\top}$ is AY442294. identified as Torulaspora delbrueckii-like and one identified as Pichia mexicana-like (Carreiro et al., 1997) were found to represent a novel species related to Sympodiomyces parvus. In this paper, the novel species Sympodiomyces attinorum sp. nov. is described.

Strains UNESP-S47, UNESP-S49 and UNESP-S156 ${ }^{\mathrm{T}}$ were isolated from the fungal garden (older sponge) and strain UNESP-S78 was recovered in a waste deposit; all four strains were isolated from laboratory nests of $A$. sexdens maintained at the Centro de Estudos de Insetos Sociais (CEIS), UNESP, Rio Claro, São Paulo, Brazil, as described by Carreiro et al. (1997). The yeasts were characterized by standard methods (Yarrow, 1998).

DNA templates were prepared as described by De Barros Lopes et al. (1996) and the PCR conditions followed were those given by Pataro et al. (2000). Primer EI1 (5'-CTGGCTTGGTGTATGT- $3^{\prime}$ ) is complementary to intron splicing sites found in mutable regions of the Saccharomyces genome (De Barros Lopes et al., 1996). PCR products were analysed by $1 \%$ agarose gel electrophoresis. Authentic strains of Debaryomyces hansenii, Pichia guilliermondii and Torulaspora delbrueckii were used for comparison.

The D1 and D2 variable domains of the large-subunit rRNA 
gene of a strain of Sympodiomyces attinorum were amplified by PCR from whole cells as described previously (Lachance et al., 1999). Amplified DNA was concentrated and cleaned on QIAquick PCR columns (Qiagen) and sequenced in an $\mathrm{ABI}$ sequencer at the John P. Robarts Research Institute, London, Ontario, Canada. The D1/D2 regions of largesubunit rRNA genes of Debaryomyces hansenii UNESPF46, Pichia guilliermondii UNESP-S170 and Torulaspora delbrueckii UFMG-B40.2 were sequenced in an ABI Prism 377 DNA sequencer at the Laboratory of Microbiology, CEIS. Sequences were edited with the program DNAMAN version 4.0 (Lynnon BioSoft). Existing sequences for other yeasts were retrieved from GenBank. The CLUSTAL_W (Thompson et al., 1994) algorithm provided in the DNAMAN package was used to align sequences and construct a neighbour-joining tree with 1000 bootstrap iterations. The sequences were edited and aligned with CLUSTAL_W (Thompson et al., 1994) and compared with existing sequences for other yeasts retrieved from GenBank.

Three yeast strains isolated from laboratory leaf-cutting ant nests were originally identified physiologically as Torulaspora delbrueckii-like (UNESP-S47, UNESP-S49, UNESP-S78) and one was identified as Pichia mexicana-like (UNESP-S156 ${ }^{\mathrm{T}}$ ) by Carreiro et al. (1997). Characterization by PCR fingerprinting with primer EI1 showed that these strains were similar to one another, but different from Debaryomyces hansenii, Pichia guilliermondii and Torulaspora delbrueckii (Fig. 1). De Barros Lopes et al. (1998) showed that primer EIl can be used to differentiate yeast species. The PCR method is simple and can

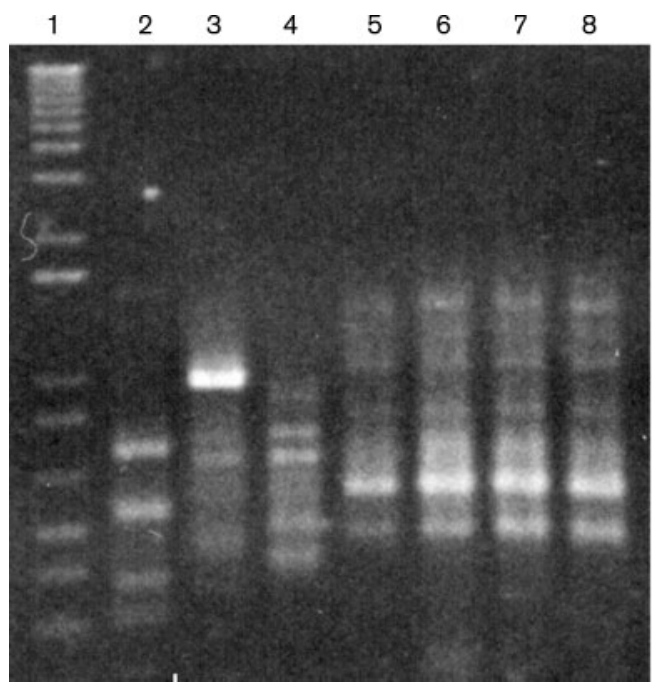

Fig. 1. PCR fingerprints of Debaryomyces hansenii, Pichia guilliermondii, Torulaspora delbrueckii and Sympodiomyces attinorum strains using primer El1. Lanes: 1, $1 \mathrm{kbp}$ ladder; 2, Debaryomyces hansenii UNESP-F46; 3, Pichia guilliermondii UNESP-S170; 4, T. delbrueckii UFMG-B40.2; 5, S. attinorum UNESP-S47; 6, S. attinorum UNESP-S49; 7, S. attinorum UNESP-S78; 8, S. attinorum UNESP-S156 ${ }^{\top}$. be used for rapid species differentiation in large numbers of yeast strains before sequencing.

Sequencing of the D1/D2 region of the large-subunit rRNA gene of strain UNESP-S156 ${ }^{\mathrm{T}}$ showed that the strain differed by 29 base substitutions from Sympodiomyces parvus, indicating that the two species are phylogenetically distinct (Fig. 2). These species are also related to the recently described Sympodiomyces indianaensis and its ascogenous sister species, Trichomonascus petasosporus (Kurtzman, 2004). Kurtzman \& Robnett (1995) had suggested that the genera Arxula, Blastobotrys and Sympodiomyces should be treated as a single genus, as they were thought to represent anamorphs of Stephanoascus species. However, they later showed that Stephanoascus species are highly divergent (Kurtzman \& Robnett, 1998) and Kurtzman (2004) recently described the genus Trichomonascus as an ascogenous counterpart to Sympodiomyces. Accordingly, this novel species is being assigned to the genus Sympodiomyces. The current description of the genus (Fell \& Statzell-Tallman, 1998) gives a very detailed description of sympodial conidiation in Sympodiomyces parvus, characterized by the accumulation of denticulate scars along a growing conidiophore. Like Kurtzman (2004), we do not construe the description to be so restrictive as to preclude the addition of species whose conidiation does not fit every detail. Formation of protuberances without conspicuous denticles (Fig. 3) is viewed as sufficiently compatible with the description not to require emendation of the genus.

The isolates of Sympodiomyces attinorum were examined after growth on common sporulation media $5 \%$ malt extract agar, corn meal agar, Fowell acetate agar and GY agar), but asci were not seen. The isolates were also mixed in pairs and no signs of conjugation were observed. It is concluded at this time that Sympodiomyces attinorum occurs in nature in the asexual form. The related species Trichomonascus petasosporus was isolated in the form of haploid mating types (Kurtzman, 2004), indicating that Sympodiomyces attinorum may be a heterothallic, ascogenous

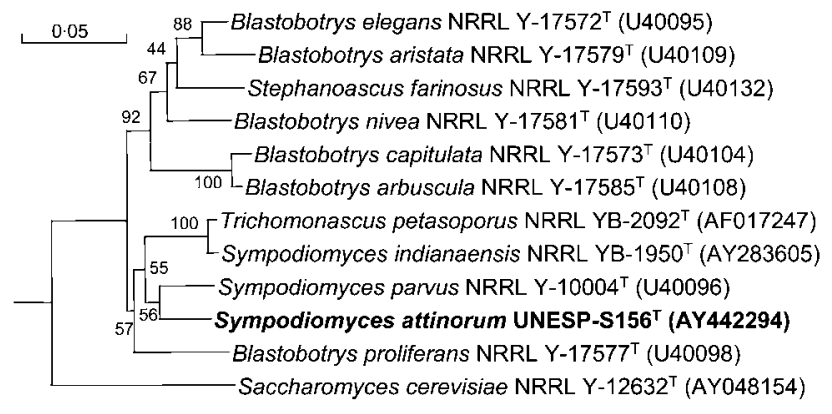

Fig. 2. Neighbour-joining phylogram based on the $D 1 / D 2$ divergent domains of the large-subunit rRNA gene of Sympodiomyces attinorum and related species. Percentage bootstrap values were obtained from 1000 iterations. Bar, 5\% sequence divergence. 


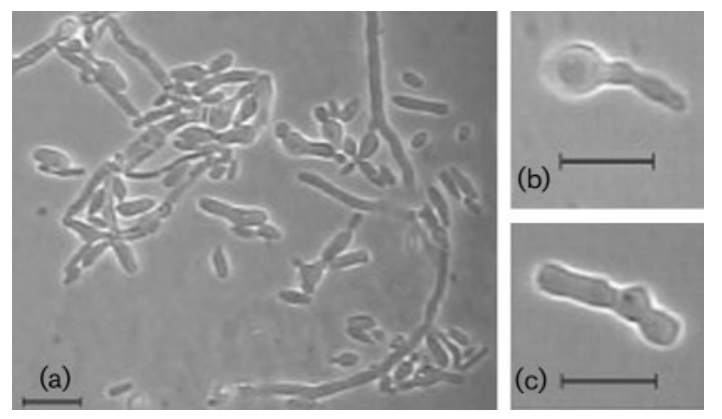

Fig. 3. Phase-contrast micrographs of Sympodiomyces attinorum UNESP-S156 ${ }^{\top}$. Vegetative cells and true mycelium (a) and conidiophore formation (b, c) after 4 days on $5 \%$ malt extract at $25^{\circ} \mathrm{C}$ are shown. Bars, $10 \mu \mathrm{m}$.

species. Unlike Sympodiomyces parvus, Sympodiomyces attinorum can ferment glucose, assimilate methyl $\alpha$-Dglucoside, salicin and citrate, and grow at $37^{\circ} \mathrm{C}$, thus enabling these two species to be distinguished. The species differs from Trichomonascus petasosporus and Sympodiomyces indianaensis by its lack of growth on trehalose and the utilization of several carbon compounds, including L-rhamnose, D-ribose, galactitol and DL-lactic acid.

Sympodiomyces parvus is considered to be indigenous to marine waters, as all strains were isolated from open Antarctic waters in the southern Indian and Pacific Oceans (Fell \& Statzell, 1971; Fell, 1976). Strains were isolated from depths of $16-748 \mathrm{~m}$, at water temperatures of $3 \cdot 1-10 \cdot 6^{\circ} \mathrm{C}$ and salinities of 33.9-34.9\%. Sympodiomyces indianaensis and Trichomonascus petasosporus were isolated in a white fungus growing on a fallen tree and in insect frass, respectively. The four strains of Sympodiomyces attinorum were isolated from laboratory nests of $A$. sexdens. The nests were maintained at about $25^{\circ} \mathrm{C}$ and about $\mathrm{pH} 5.0$ in the older sponges and $\mathrm{pH} 6.0$ in the waste deposits (Carreiro, 1994; Carreiro et al., 1997). Three strains were isolated from the fungal garden (older sponge) and one was from a waste deposit. Most yeast species in this community have the ability to degrade the plant polysaccharides pectin, starch and carboxymethylcellulose. All four strains of Sympodiomyces attinorum degraded soluble starch and strains UNESP-S47, UNESP-S78, UNESP-S156 ${ }^{\mathrm{T}}$ degraded pectin and polygalacturonic acid. Strain UNESP-S156 ${ }^{\mathrm{T}}$, however, was able to degrade carboxymethylcellulose (Carreiro, 2000). These results show that S. attinorum can contribute to the degradation of plant polysaccharides present in the ant nest.

\section{Latin diagnosis of Sympodiomyces attinorum Carreiro, Pagnocca, Rosa et Lachance sp. nov.}

In medio liquido post dies 4 cellulae singulae, binae, aut in catenis brevis; cellulae ovoidae aut elongatae $(5 \cdot 5-7 \cdot 0 \times 2 \cdot 0$ $3.5 \mu \mathrm{m})$. Cultura in agaro malti post tres dies $\left(25^{\circ} \mathrm{C}\right)$ convexa, glabra, cremea et butyrosa. In agaro farinae Zea mays post dies 14 pseudomycelium et mycelium verum formantur. Glucosum et maltosum (variable) fermentatur. Glucosum, galactosum, L-sorbosum, glucosaminum, D-ribosum, D-xylosum, L-arabinosum, D-arabinosum, L-rhamnosum, maltosum, methyl $\alpha$-D-glucosidum, cellobiosum, salicinum, amylum solubile, glycerolum, erythritolum, ribitolum, xylitolum, L-arabinitolum, glucitolum, mannitolum, galactitolum, $\mathrm{N}$ acetylglucosaminum, meso-inositolum et acidum lacticum assimilantur, at non sucrosum, trehalosum, melibiosum, lactosum, raffinosum, melezitosum, inulinum, D-glucono1,5-lactonum, 2-ketogluconatum, 5-ketogluconatum, acidum gluconicum, acidum glucuronicum, acidum succinicum, acidum citricum, methanolum, ethanolum nec hexadecanum. Lysinum, cadaverinum et ethylaminum assimilantur, at non natrium nitricum nec natrium nitrosum. Ureum non finditur. Diazonium caeruleum B negativum. Ad crescentiam vitaminae externae necessariae sunt. Augmentum in $37^{\circ} \mathrm{C}$. Materia amyloidea non formatur. Crescit in agaro extracto fermenti cum $50 \%$ glucoso et in agaro extracto fermenti cum $10 \%$ $\mathrm{NaCl}$. Crescit in medio $10 \mu \mathrm{m}$ cycloheximido $\mathrm{ml}^{-1}$ addito. Habitat nidum Attae sexdentis, Sao Paolo, Brazil. Typus UNESP-S156 ${ }^{\mathrm{T}}$. In collectione zymotica Centraalbureau voor Schimmelcultures, Trajectum ad Rhenum, sub no. CBS $9734^{\mathrm{T}}$ typus stirps deposita est.

\section{Description of Sympodiomyces attinorum Carreiro, Pagnocca, Rosa et Lachance sp. nov.}

Sympodiomyces attinorum (N.L. gen. masc. n. attinorum of Attini, referring to the tribe Attini, to which Atta sexdens belongs).

In yeast extract $(0.5 \%)$-glucose $(2 \%)$ broth after 4 days at $25^{\circ} \mathrm{C}$, cells are elongate, ovoid and subglobose and occur singly, in pairs or in short branched chains $(5 \cdot 5-7 \cdot 0 \times 2 \cdot 0-$ $3.5 \mu \mathrm{m}$ ), with formation of true hyphae (Fig. 3). On yeast extract-malt extract agar after 2 days at $25^{\circ} \mathrm{C}$, colonies are dull cream, convex, rugose and butyrous. In Dalmau plate cultures on cornmeal agar after 2 weeks, true mycelium is formed with distinct septa and clusters of conidia. Glucose and maltose (variable) are fermented. Assimilates the following carbon compounds: glucose, galactose, L-sorbose, D-glucosamine, D-ribose, D-xylose, L-arabinose, D-arabinose, L-rhamnose, maltose, methyl $\alpha$-D-glucoside, cellobiose, salicin, soluble starch (weak), glycerol, erythritol, ribitol, xylitol, L-arabinitol, glucitol, mannitol, galactitol, inositol, $\mathrm{N}$-acetyl-D-glucosamine, D-gluconate (weak), DL-lactate. No growth occurs on sucrose, trehalose, melibiose, lactose, raffinose, melizitose, inulin, D-glucono-1,5-lactone, 2-keto-D-gluconate, 5-ketoD-gluconate, D-glucuronate, succinate, citrate, methanol, ethanol or hexadecane. Does not assimilate nitrate or nitrite, but does assimilate ethylamine, lysine and cadaverine. Urease activity and Diazonium blue B reaction are negative. Growth in amino-acid-free medium is positive, but negative in vitamin-free medium and in $1 \%$ acetic acid. Growth at $37^{\circ} \mathrm{C}$ is positive. Acid formation on chalk agar and casein hydrolysis are positive. Starch formation is negative. Growth on $50 \%$ glucose-yeast extract agar and YM 
agar with $10 \% \mathrm{NaCl}$ is positive. Growth in the presence $0 \cdot 1 \%$ cycloheximide is positive.

Isolated from nests of the leaf-cutting ant Atta sexdens in Brazil. The type strain of Sympodiomyces attinorum is strain UNESP-S156 ${ }^{\mathrm{T}}\left(=\mathrm{CBS} 9734^{\mathrm{T}}=\right.$ NRRL Y-27639 $\left.{ }^{\mathrm{T}}\right)$. This strain was isolated in 1996 from older sponge of a laboratory nest of $A$. sexdens maintained at the Centro de Estudos de Insetos Sociais (CEIS), UNESP, Rio Claro, São Paulo, Brazil.

\section{Acknowledgements}

This work was funded by the Conselho Nacional de Desenvolvimento Científico e Tecnológico of Brazil (CNPq - process nos 151016/2002-0 and 62.0477/98-2), Fundação de Amparo à pesquisa do Estado de São Paulo (FAPESP - process no. 95/09101-4) and by the Natural Science and Engineering Research Council of Canada (M.-A. L.). We thank C. P. Kurtzman for sharing pre-publication data.

\section{References}

Carreiro, S. C. (1994). Ecologia e taxonomia de leveduras associadas às formigas cortadeiras da espécie Atta sexdens rubropilosa Forel, 1908. MSc dissertation, UNESP, Rio Claro, São Paulo, Brazil.

Carreiro, S. C. (2000). Pesquisa de fator killer e análise da degradação de polissacarídeos vegetais por leveduras associadas aos ninhos de Atta sexdens. PhD thesis, UNESP, Rio Claro, São Paulo, Brazil.

Carreiro, S. C., Pagnocca, F. C., Bueno, O. C., Bacci, M., Jr, Hebling, M. J. A. \& da Silva, O. A. (1997). Yeasts associated with nests of the leaf-cutting ant Atta sexdens rubropilosa Forel, 1908. Antonie van Leeuwenhoek 71, 243-248.

De Barros Lopes, M., Soden, A., Henschke, P. A. \& Langridge, P. (1996). PCR differentiation of commercial yeast strains using intron splice site primers. Appl Environ Microbiol 62, 4514-4520.
De Barros Lopes, M., Soden, A., Martens, A. L., Henschke, P. A. \& Langridge, P. (1998). Differentiation and species identification of yeasts using PCR. Int J Syst Bacteriol 48, 279-286.

Fell, J. W. (1976). Yeasts in oceanic regions. In Recent Advances in Aquatic Mycology, pp. 93-124. Edited by E. B. G. Jones. London: Elek Science.

Fell, J. W. \& Statzell, A. C. (1971). Sympodiomyces gen. n., a yeast-like organism from southern marine waters. Antonie van Leeuwenhoek 37, 359-367.

Fell, J. W. \& Statzell-Tallman, A. (1998). Sympodiomyces Fell \& Statzell. In The Yeasts, a Taxonomic Study, 4th edn, pp. 603-604. Edited by C. P. Kurtzman \& J. W. Fell. Amsterdam: Elsevier.

Kurtzman, C. P. (2004). Trichomonascus petasosporus sp. nov. and Sympodiomyces indianaensis sp. nov., two new members of the Saccharomycetales. Antonie van Leeuwenhoek 85, 297-304.

Kurtzman, C. P. \& Robnett, C. J. (1995). Molecular relationships among hyphal ascomycetous yeasts and yeast like taxa. Can J Bot 73, S824-S830.

Kurtzman, C. P. \& Robnett, C. J. (1998). Identification and phylogeny of ascomycetous yeasts from analysis of nuclear large subunit (26S) ribosomal DNA partial sequences. Antonie van Leeuwenhoek 73, 331-371.

Lachance, M. A., Bowles, J. M., Starmer, W. T. \& Barker, J. S. F. (1999). Kodamaea kakaduensis and Candida tolerans, two new ascomycetous yeast species from Australian Hibiscus flowers. Can J Microbiol 45, 172-177.

Pataro, C., Guerra, J. B., Petrillo-Peixoto, M. L., Mendonça-Hagler, L. C., Linardi, V. R. \& Rosa, C. A. (2000). Yeast communities and genetic polymorphism of Saccharomyces cerevisiae strains associated with artisanal fermentation in Brazil. J Appl Microbiol 89, 24-31.

Thompson, J. D., Higgins, D. G. \& Gibson, T. J. (1994). CLUSTAL_W: improving the sensitivity of progressive multiple sequence alignment through sequence weighting, position-specific gap penalties and weight matrix choice. Nucleic Acids Res 22, 4673-4680.

Yarrow, D. (1998). Methods for the isolation, maintenance, and identification of yeasts. In The Yeasts, a Taxonomic Study, 4th edn, pp. 77100. Edited by C. P. Kurtzman \& J. W. Fell. Amsterdam: Elsevier. 